\title{
Relationship between Angiotensin Converting Enzyme Gene I/D Polymorphism and Muscle Strength in Elderly
}

\author{
Takuro Tobina*, Makoto Ayabe ${ }^{*, * * * * * *}$, Yutaka Yoshitake ${ }^{* *}$, Yasuo Kimura ${ }^{* * *}$, \\ Hideo Miyazaki ${ }^{* * * *}$, Kojiro Ishii ${ }^{*}$, Bo Zhang ${ }^{* * * *}$, Keijiro Saku ${ }^{* * * *}$, \\ Munehiro Shindo $^{* * * * * *}$, Akira Kiyonaga ${ }^{* * * * *}$ and Hiroaki Tanaka ${ }^{* *}$ \\ * Graduate School of Education, Hokkaido University \\ Nishi 7, Kita 11-jo, Kita-ku, Sapporo City, Hokkaido 060-0811 Japan \\ tobitaku@ck9.so-net.ne.jp \\ ** National Institute of Fitness and Sports in Kanoya \\ 1 Siromizu-cho, Kanoya City, Kagoshima 891-2393 Japan \\ ${ }^{* * *}$ Faculty of Culture and Education, Saga University \\ 1 Honjo-cho, Saga City, Saga 840-8502 Japan \\ ${ }^{* * *}$ Graduate School of Medicine and Dental Science, Niigata University \\ 2-5274 Gakko-cho, Niigata City, Niigata 951-8514 Japan \\ ${ }^{* * * * *}$ Fukuoka University School of Medicine \\ 7-45-1 Nanakuma, Jonan-ku, Fukuoka City, Fukuoka 814-0180 Japan \\ ${ }^{* *}$ Faculty of Sports and Health Science, Fukuoka University \\ 8-19-1 Nanakuma, Jonan-ku, Fukuoka City, Fukuoka 814-0141 Japan \\ ******* Department of Exercise Physiology, School of Health and Sports Science, Juntendo University \\ 1-1, Hiragagakuendai, Inba-Mura, Inba-Gun, Chiba, 270-1606 Japan \\ [Received May 20, 2005 ; Accepted July 20, 2005]
}

\begin{abstract}
Previous studies have indicated that the Angiotensin I converting enzyme (ACE) gene insertion/deletion (I/D) polymorphism could influence human physical performance. Furthermore, a study has suggested that ACE inhibitor treatment might decrease long-term decline in muscle strength in elderly women. Thus we hypothesized that the I allele of ACE gene I/D polymorphism, which relates to lower ACE activity, might be associated with slow-decline of muscle strength in the elderly. One hundred ninety elderly people aged 72 were recruited for this study. We assessed isometric knee extension strength, leg extension power and grip strength every year for 4 years.In the preliminary measurements, physical characteristics and muscle strength were not significantly different among three genotypes. Age-related changes of the isometric knee extension, leg extension power, grip strength were similar among three genotypes. The results of this investigation suggest that ACE gene I/D polymorphism does not affect age-related change of muscle strength in the elderly.
\end{abstract}

Keywords: Angiotensin I converting enzyme, Polymorphism, Aging

[International Journal of Sport and Health Science Vol.4, 460-464, 2006]

\section{Introduction}

Age-related physical changes are affected by various factors. Especially, genetic factors are predominant in these changes. This is because aging speed and lifespan converge in the same species (Hekimi et al., 2003; Browner et al., 2004). One recent study investigating human longevity and genetic factors reports the angiotensin I converting enzyme (ACE) gene Insertion (I) Deletion (D) polymorphism to be a candidate for important related factors (Schachter et al., 1994).

ACE is a key enzyme in the blood pressure regulation system which produces vasoconstrictor angiotensin II (Ang II) from angiotensin I (Ang I). Ang II stimulates water and sodium retention in oder to facilitate aldosterone secretion in the adrenal glands. Furthermore, ACE inactivates the bradykinin (BK). As a result the enzyme increases blood pressure. 
The human ACE gene is codified in $17 \mathrm{q} 23$. ACE gene $\mathrm{I} / \mathrm{D}$ polymorphism is decided by the presence or absence of genes on intron 16 of 287 base pairs. ACE gene I/D polymorphism consists of three genotypes: I allele homozygous (I/I), D allele homozygous (D/D), and heterozygous (I/D). ACE activity of serum and tissue is significantly lower in I/I than D/D while I/D stands in the middle (Rigat et al., 1990; Danser et al., 1995).

Many reports indicate ACE gene I/D polymorphism as a genetic factor influential in physical performance (Montgomery et al., 1998; Gayagay et al., 1998; Hagberg et al., 1998; Woods et al., 2001). The finding in our previous study that ACE gene I/D polymorphism is one of the genetic factors determining human skeletal muscle fiber composition supports the phenomenon that this polymorphism is associated with physical performance (Zhang et al., 2003). Also, recent reports suggest an ACE inhibitor has an effect on improvement of physical performance (Vescovo et al., 1998) and that it inhibits decline of muscle strength with age (Onder et al., 2002). Thus, we hypothcsize that chronically lower ACE activity prevents decline of age-related muscle strength.

The purpose of this study is to examine the relationship between ACE gene I/D polymorphism and age-related change of muscle strength by a follow-up study of the elderly.

\section{Method}

\subsection{Subjects}

We randomly selected 600 elderly living in Niigata Prefecture in Japan who turned 72 years old in 2000, and from that group we identified 190 subjects who fulfilled four years of physical examinations conducted in June every year from 2000 to 2004 . We received informed consent from all the subjects. This study was approved by the Ethics Committee of the Faculty of Dentistry at Niigata University.

\subsection{ACE gene polymorphism}

We extracted genomic DNA from peripheral blood leukocytes and amplified the I and D allele of ACE gene I/D polymorphism by polymerase chain reaction (PCR). The PCR products of $490 \mathrm{bp}$ and $290 \mathrm{bp}$ were separated on $1.5 \%$ agarose gel and visualized by ethidium bromide staining, as previously described by Zhang et al. (2003).

\subsection{Muscle strength measurement}

We evaluated isometric knee extension strength, leg extension power, and grip strength. For isometric knee extension strength, the subjects were asked to sit on a chair and attach both ankles to a belt that was connected to a loadcell. Strength was measured through maximum isometric tension when their knees were extended to ninety degrees. We measured leg extension power five times by a leg extension power measuring device (Anaeropress-3500, Combi: Japan) and used the means of the two greatest measurements. For grip strength, we measured right and left twice using a smedley hand dynamometer (DM-100s, Yagami: Japan) and took the maximum value.

\subsection{Statistical analysis}

ANOVA was used to compare the measured values of the first year with $\mathrm{I} / \mathrm{I}, \mathrm{I} / \mathrm{D}$, and $\mathrm{D} / \mathrm{D}$ of ACE gene I/D polymorphism. Repeated 2-way ANOVA was used to compare the age-based changes of knee extension strength, leg extension power, and grip strength among the polymorphisms with a significance level less than $5 \%$.

\section{Result}

The frequency of ACE gene I/D polymorphism was 77 (50 males and 27 females) in I/I, 85 (52 males and 33 females) in I/D, and 28 (18 males and 10 females) in D/D, Hardy-Weinberg equilibrium was established.

Height, weight, knee extension strength, leg extension power, and grip strength obtained in the measurement of the first year did not show any difference among the ACE gene I/D polymorphisms (Table 1). No significant difference was observed in the change of knee extension strength, leg extension power, and grip strength with time during four years among the ACE gene I/D polymorphisms (Figure 1).

\section{Discussion}

Many studies have reported a possibility of influence of the ACE gene I/D polymorphism on 
Table 1 Characteristics and muscle strength at baseline of the subjects.

\begin{tabular}{lccc}
\hline & \multicolumn{1}{c}{$\mathrm{I} / \mathrm{I}$} & $\mathrm{I} / \mathrm{D}$ \\
$\mathrm{N}=77$ & $\mathrm{~N}=85$ & $\begin{array}{c}\mathrm{D} / \mathrm{D} \\
\mathrm{N}=28\end{array}$ \\
\hline $\begin{array}{l}\text { Height } \\
(\mathrm{cm})\end{array}$ & $158.1 \pm 8.2$ & $158.2 \pm 8.2$ & $156.5 \pm 7.0$ \\
$\begin{array}{l}\text { Body weight } \\
\text { (kg) }\end{array}$ & $54.7 \pm 9.8$ & $56.4 \pm 8.7$ & $54.9 \pm 8.0$ \\
$\begin{array}{l}\text { Isometric knee extension } \\
\text { strength (kg) }\end{array}$ & $62.1 \pm 22.2$ & $57.6 \pm 16.0$ & $62.8 \pm 15.0$ \\
$\begin{array}{l}\text { Leg extension power } \\
\text { (watts) }\end{array}$ & $751.0 \pm 326.3$ & $765.2 \pm 303.8$ & $702.4 \pm 286.6$ \\
$\begin{array}{l}\text { Grip strength } \\
\text { (kg) }\end{array}$ & $35.2 \pm 8.5$ & $36.1 \pm 9.0$ & $35.3 \pm 8.0$ \\
\hline
\end{tabular}

Values are given as mean \pm SD

physical performance. Furthermore, two reliable studies suggest that the gene polymorphism may control lifespan and that long-term use of an ACE inhibitor may curb weakening of muscle strength with age. Thus, we examined if ACE gene I/D polymorphism, which has a great influence on ACE activity, might affect change of age-related muscle strength. Contrary to our hypothesis, knee extension strength, leg extension power, and grip strength did not show any differences among the polymorphisms.

Muscle strength declines with age (Gallagher et al., 1997). If ACE gene I/D polymorphism is a genetic factor strongly influential in the change of age-related muscle strength, some differences should have been recognized in 2000 when the subjects turned 72 . The present study did not observe any differences either in the change of muscle strength in the first year or the four-year age-based change of muscle strength among the ACE gene I/D polymorphisms. From our longitudinal and lateral observation of the present study, there was no relation between ACE gene I/D polymorphism and the change of age-related muscle strength.

Onder et al., have suggested reduction in inflammatory responses to slow the decreases in muscle strength with age by prolonged use of an ACE inhibitor (Onder et al., 2002). The pathway of a decrease of inflammatory reactant, as they exemplified, includes increase of nitrogen monoxide (NO) through ACE inhibition-mediated BK increase (De Caterina et al., 1995) and decrease of interleukin-6 (IL-6) and tumor necrosis factor alpha (TNF- $\alpha$ ) through inhibition of nuclear factor $\mathrm{kB}$ (NF-kB) from entering into the nucleus by a decrease of Ang II (Han et al., 1999; Ross, 1993). Because ACE activity is lower in $\mathrm{I} / \mathrm{I}$ than $\mathrm{D} / \mathrm{D}$ among the ACE gene I/D polymorphisms, BK is inactivated less and Ang II is produced less in I/I. In previous studies, however, no difference was observed between BK at rest and Ang II among the ACE gene I/D polymorphisms (Murphey et al., 2000; Lachurie et al., 1995). Thus, it demonstrates little possibility of influence of ACE gene I/D polymorphism on production of inflammatory reactant.

The result of the present study suggests that ACE gene $\mathrm{I} / \mathrm{D}$ polymorphism is not the factor affecting the change of age-related muscle strength.

\section{Acknowledgement}

This study was carried out from 1999 to 2004 as a project of Science and Technology Promotion Adjustment Cost Inhabitant Needs Research of the Japanese Ministry of Education, Culture, and Science with Research Funds Base Study B 15300229 from the Ministry of Education, Culture, and Science and with Education Improvement Promotion Funds 2003 (Yoshitake Yutaka) from the National Institute of Fitness and Sports in Kanoya. We wish to express our gratitude here. 

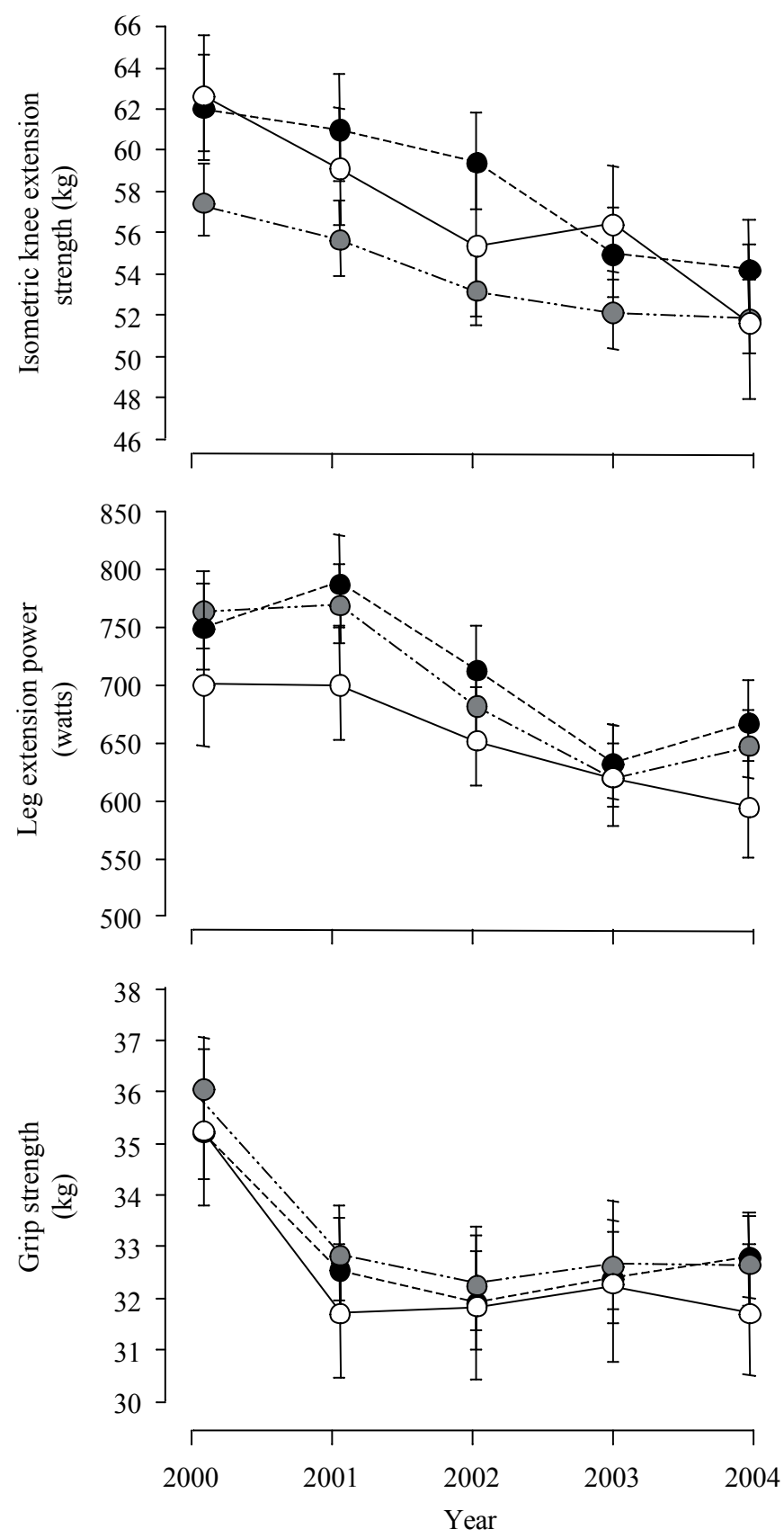

Figure 1 Changes in muscle strength in I/I (---------), I/D ( -..-O-... ) and D/D ( - - $)$ genotype of angiotensin I converting enzyme gene I/D polymorphism. Data are shown as mean and SE.

\section{References}

Browner WS, Kahn AJ, Ziv E, Reiner AP, Oshima J, Cawthon RM, Hsueh WC, Cummings SR. (2004). The genetics of human longevity. Am J Med., 117:851-860.

Danser AH, Schalekamp MA, Bax WA, van den Brink AM, Saxena PR, Riegger GA, Schunkert H. (1995). Angiotensin-converting enzyme in the human heart. Effect of the deletion/insertion polymorphism. Circulation, 92:1387-8.

De Caterina R, Libby P, Peng HB, Thannickal VJ, Rajavashisth TB, Gimbrone MA Jr, Shin WS, Liao JK. (1995). Nitric oxide decreases cytokine-induced endothelial activation. Nitric oxide selectively reduces endothelial expression of adhesion molecules and proinflammatory cytokines. J Clin Invest., 96:60-68.

Gallagher D, Visser M, De Meersman RE, Sepulveda D, Baumgartner RN, Pierson RN, Harris T, Heymsfield SB. (1997). Appendicular skeletal muscle mass: effects of age, gender, and ethnicity. J Appl Physiol., 83:229-239.

Gayagay G, Yu B, Hambly B, Boston T, Hahn A, Celermajer DS, Trent RJ. (1998). Elite endurance athletes and the ACE I allele -the role of genes in athletic performance-. Hum Genet., 103:48-50.

Hagberg JM, Ferrell RE, McCole SD, Wilund KR, Moore GE. (1998). VO2 max is associated with ACE genotype in postmenopausal women. J Appl Physiol., 85:1842-1846

Han Y, Runge MS, Brasier AR. (1999). Angiotensin II induces interleukin-6 transcription in vascular smooth muscle cells through pleiotropic activation of nuclear factor-kappa B transcription factors. Circ Res., 84:695-703.

Hekimi S, Guarente L. (2003). Genetics and the specificity of the aging process. Science, 299:1351-1354.

Montgomery HE, Marshall R, Hemingway H, Myerson S, Clarkson P, Dollery C, Hayward M, Holliman DE, Jubb M, World M, Thomas EL, Brynes AE, Saeed N, Barnard M, Bell JD, Prasad K, Rayson M, Talmud PJ, Humphries SE. (1998). Human gene for physical performance. Nature, 393:221-222.

Lachurie ML, Azizi M, Guyene TT, Alhenc-Gelas F, Menard J. (1995). Angiotensin-converting enzyme gene polymorphism has no influence on the circulating renin-angiotensin-aldo sterone system or blood pressure in normotensive subjects. Circulation, 91:2933-2942.

Onder G, Penninx BW, Balkrishnan R, Fried LP, Chaves PH, Williamson J, Carter C, Di Bari M, Guralnik JM, Pahor M. (2002). Relation between use of angiotensin-converting enzyme inhibitors and muscle strength and physical function in older women: an observational study. Lancet, 359:926-930.

Rigat B, Hubert C, Alhenc-Gelas F, Cambien F, Corvol P, Soubrier F. (1990). An insertion/deletion polymorphism in the angiotensin I-converting enzyme gene accounting for half the variance of serum enzyme levels. J Clin Invest., 86:1343-1346.

Ross R. (1993). The pathogenesis of atherosclerosis: a perspective for the 1990s. Nature, 362:801-809.

Schachter F, Faure-Delanef L, Guenot F, Rouger H, Froguel P, Lesueur-Ginot L, Cohen D. (1994). Genetic associations with human longevity at the APOE and ACE loci. Nat Genet., 6:29-32.

Vescovo G, Dalla Libera L, Serafini F, Leprotti C, Facchin L, Volterrani M, Ceconi C, Ambrosio GB. (1998). Improved exercise tolerance after losartan and enalapril in heart failure: correlation with changes in skeletal muscle myosin heavy chain composition. Circulation, 98:1742-1749.

Woods D, Hickman M, Jamshidi Y, Brull D, Vassiliou V, Jones A, Humphries S, Montgomery H. (2001). Elite swimmers and the D allele of the ACE I/D polymorphism. Hum Genet., 108:230-232.

Zhang B, Tanaka H, Shono N, Miura S, Kiyonaga A, Shindo M, Saku K. (2003). The I allele of the angiotensin-converting enzyme gene is associated with an increased percentage of slow-twitch type I fibers in human skeletal muscle. Clin Genet., 63:139-144. 


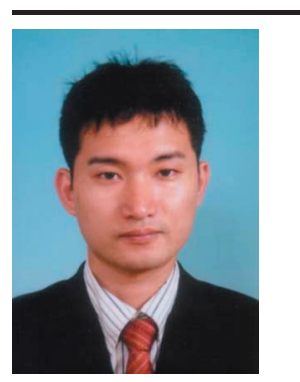

Name:

Takuro Tobina

\section{Affiliation:}

Graduate School of Education, Hokkaido University

\section{Address:}

Nishi 7, Kita 11-jo, Kita-ku, Sapporo City, Hokkaido 060-0811 Japan Brief Biographical History:

2000- Master's Program, Graduate School of Physical Educatin, Fukuoka University.

2002- Doctoral Program, Graduate School of Education, Hokkaido University.

Membership in Learned Societies:

- The Japanese Society of Physical Fitness and Sports Medicine. 